\title{
ナノバイオ技術を用いた新規培養システムの開発
}

\author{
谷口彰良, ${ }^{*}$ 和田健一, 大野まき
}

\section{Development of Novel Culture System Using Nano-biotechnology}

\author{
Akiyoshi TANIGUCHI, ${ }^{*}$ Ken-ichi WADA, and Maki OHNO \\ Advanced Medical Materials Group, Biomaterials center, National Institute \\ for Materials Science, 1-1 Namiki, Tsukuba, Ibaraki 305-0044, Japan
}

(Received October 1, 2009)

\begin{abstract}
We have developed two cell culture systems for use in pharmaceutical research using nano-biotechnology. First, we developed a double layered co-culture system using cell sheet technology, and showed that in a layered co-culture system with HepG2 and bovine endothelial cells, the expression levels of various cytochrome P450 (CYP) genes were significantly increased compared to monolayer cultured HepG2 cells. In the layered HepG2 co-culture, expression of the CYP2C and CYP3A family genes was induced by phenobarbital treatment. We also detected CYP3A4 enzyme induction using this co-culture system. Next, we developed sensor cells. Living cells maintain homeostasis by responding quickly and with great sensitivity to changes in the external environment. Consequently, sensors using cells as active elements are thought to be able to perform analyses faster and with more sensitivity than previous methods. We have modified mammalian cells using genetic engineering techniques to develop next-generation cell sensors that can visually represent specific reactions. We successfully produced devices using sensor cells that can process a variety of specimens using Micro-Electro-Mechanical System (MEMS), Nano-Electro-Mechanical System (NEMS), and other nano/micro processing technologies. These systems may serve as a useful model for in vitro pharmacological studies on the coordinated regulation of metabolism and cytotoxicity. In this review, we introduce our research and describe recent trends in this field.
\end{abstract}

Key words - hepatocyte; cytochrome p450 (CYP); co-culture; gene expression; Micro-Electro-Mechanical System (MEMS) ; cytotoxity

\section{1. はじめに}

近年, 動物実験は動物愛護の観点から極力減らす ことが望まれている。 また，一方で多くの薬物に対 する作用・副作用には種差が報告され，ヒトにおけ る薬物代謝や毒性を動物実験の結果から予測するこ とは難しい。そこで，ヒト培養細胞を用いた in vitro の医薬品の代謝や毒性などを調べることがで きる実験系が求められる。しかし，細胞は通常の 2 次元培養では機能が著しく低下し, in vivo を反映 させることは難しい. 特に，肝細胞は培養数日で機 能が著しくて低下してしまう。肝蔵などの組織は異 なった細胞種が 3 次元的にコミュニケーションを取

独立行政法人物質・材料研究機構生体材料センター先 端医療材料グループ（下305-0044 つくば市並木 1-1）

*e-mail: taniguchi.akiyoshi@nims.go.jp

本総説は, 日本薬学会第 129 年会シンポジウムS24 で 発表したものを中心に記述したものである.
りつつ, 臓器を形成している.この相互作用が肝臟 の機能に重要であると考えられている．通常の細胞 培養は純化された細胞を 2 次元的に培養するもので, in vivo とは全く異なった環境になっている. 特 に，細胞株の場合，このような培養ではほとんど in vivo を反映することは期待できない.

一方で，近年のナノテクノロジーとバイオテクノ ロジーの発展はめざましいものがある，そこで，こ の新技術を利用して新しい細胞培養技術の開発が可 能になってきている。例えば，ナノテクノロジーを 利用することで，細胞の重層化が可能になり，異な つた種類の細胞を 3 次元的に共培養することができ るようになってきている，この培養系では, 細胞一 細胞間相互作用が in vivoに近い状態になってい る。したがって，in vivo を反映する培養系になる ことが期待できる．また，ナノ加工技術を利用する ことで, 細胞培養をチップ化することが可能になつ 
ている，ナノ加工技術を利用することにより，いわ ゆるハイスループット化が可能になり，医薬品のス クリーニングに適した培養系を供給することができ る．また，バイオテクノロジーを用いることで細胞 に機能を付加することにより新しい分析手法が可能 になってきている，遺伝子のプロモーターと蛍光・ 発光タンパク質を導入して，特定のシグナルだけを 可視化することにより医薬品の細胞毒性などを検出 することも可能になってきている.

そこで，筆者らはナノバイオテクノロジーを利用 して 2 つの培養系を開発している. 1 つは肝・内皮 重層化培養である。培養肝細胞は医薬品の代謝試験 などに用いられているが，その機能は培養後急速に 消失していく．また，細胞株は機能が著しくて低下 している。これは，異種間の細胞一細胞相互作用が 失われているためと考えられる。肝実質細胞は内皮 細胞を介して物質の取込みや代謝を行っている。 そ こで，このような生体内の細胞環境を in vitro で再 現すれば細胞の機能が維持できると考えた。われわ れは温度感受性培養血上に血管内皮細胞を培養し, 肝細胞株上に重層化することで肝細胞の機能を上昇 させることに成功している，特に，CYP 遺伝子群 の発現が著しく上昇しており薬物による誘導も確認 できる．もう 1 つは細胞をセンサ化（センサ細胞） し, 細胞毒性を高感度に測定するシステムである. 熱ショックタンパク質 70B' (HSP70B') のプロモー ターとその下流にレポーター遺伝子を組み込んだプ ラスミドを導入しセンサ細胞を作成した. HSP70B' はタンパク変性など様々な細胞毒性に応答すること が知られている．この細胞は塩化カドミウムの毒性 を高感度に検出することができた. さらに，ナノ加 工技術を用いてマイクロ流路を作成し，この中で細 胞毒性を検出することに成功している. マイクロ流 路内は表面張力が優位に働くため乱流が起こらず層 流が形成される，この層流を利用することで多検体 同時測定が可能である。 また，検体量も微量ですむ という利点がある。本誌上シンポジウムではこれら の培養システムを紹介し, 創薬支援への応用につい て考察したい.

\section{2. 生体を模倣した肝・内皮重層化培養法による 薬物代謝試験}

多くの薬物に対する代謝反応には種差が報告さ れ，ヒトにおける代謝を動物実験の結果から予測す
ることは難しい。このため，ヒト肝組織を薬物代謝 実験に用い，ヒトの in vivo 代謝を予測する試みが 重視されている。 ヒト初代培養肝細胞は，薬剤代謝 に関与する遺伝子の発現が高く, ${ }^{1,2}$ cytochrome P450（CYP）など薬物代謝酵素の機能や薬剤の CYP 誘導能3,4) 解析するための有用な in vitro 評 価系である. ${ }^{5-7)} し か し ， ヒ ト$ 初代培養肝細胞は倫 理上も含めた種々の制約から入手が困難である。ま た, 肝機能や増殖能力は細胞分離後急速に減少し, 特に，薬物代謝酵素の活性低下は顕著である。 ${ }^{8)} こ$ のため，ヒト肝細胞としての機能をより長期間保持 した, 安定供給可能な培養系の確立が必要とされて いる.

そこで，われわれはヒト肝細胞の特徵を保持した 細胞株として汎用されている HepG2 を用いて新た な培養系を作製することにした。 HepG2 は増殖能 が高く安定供給が可能である。しかし，従来の単独 培養下では初代培養肝細胞に比べて，アルブミンや CYP を始めとする薬物代謝関連遺伝子の発現が極 めて低い。9,10) そこで, 肝臓の構造を模倣した培養 系を構築することで, HepG2 の肝細胞機能の活性 化が期待できると考えた。肝臓は肝細胞（肝実質細 胞）と，非実質細胞である内皮細胞などからなる肝 小葉を基本単位とし（Fig. 1)，これらの細胞の相 互作用によって肝臓の多様な機能が維持されてい る. 肝細胞と内皮細胞は基底膜に似た細胞外マトリ ックス（ECM）成分を含むディッセ腔を介して， 異種細胞のシートを重層したような構造で隣接して いる. そこで本研究では, 肝細胞と内皮細胞の異種 細胞を用いて肝小葉の立体構造を模倣した培養系の 構築を試みた。

われわれは肝小葉構造を模倣した細胞培養系の構

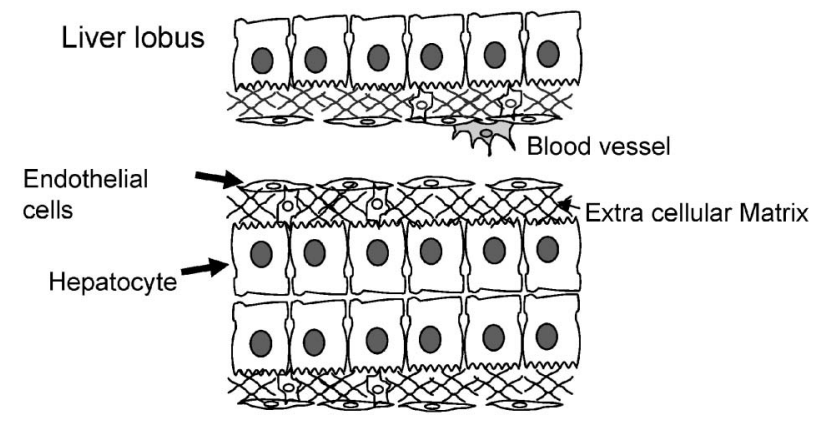

Fig. 1. Structure of Liver Lobus 


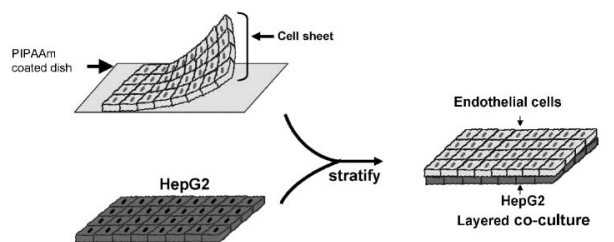

Fig. 2. Schematic Representation of the Construction of the Layered Co-culture System Using Temperature-sensitive Polymer Grafted Surfaces

Endothelial cells are seeded on the PIPAAm-coated dishes and endothelial cell sheets grown at $37^{\circ} \mathrm{C}$. The temperature is decreased to $20^{\circ} \mathrm{C}$ to induce the detachment of endothelial cell sheets; endothelial cell sheets are stratified to HepG2 and assembled into a layered co-culture system.

築を目指し，温度応答性培養血 (UpCell，セルシー ド社）を用いて，肝細胞と血管内皮細胞の単層培養 組織を重層化した共培養法を作成した（Fig. 2)。 東京女子医科大学の岡野教授により開発された温度 応答性培養血は，温度応答性高分子であるポリ $N$ イソプロピルアクリルアミド（PIPAAm）をナノ レベルの薄さで電子線で重合させ，培養血表面に共 有結合により固定化したものである. PIPAAm は, $32^{\circ} \mathrm{C}$ に下限臨界溶液温度を持つ。このため, 水中 では $32^{\circ} \mathrm{C} よ り$ 低温で疎水性のイソプロピル基周辺 の水分子がクラスター構造を形成し，親水性表面と なる。一方， $32^{\circ} \mathrm{C} よ り$ 高温ではクラスター構造が 壊れ，疎水基同士が凝集した構造となるために脱水 和状態を示し，疎水性表面となる。通常の細胞培養 条件下 $\left(37^{\circ} \mathrm{C}\right)$ では, 細胞は良好に接着し増殖する が，培養温度を $32^{\circ} \mathrm{C}$ 以下に保つと表面は親水性に 変化し, 細胞は自発的に脱離する。細胞を密な状態 で培養すると， 細胞と ECM，細胞間の接着を保持 したまま細胞シートとして回収できる。この技術で は, タンパク質分解酵素を用いた従来の細胞回収法 とは異なり, 細胞膜表面に発現している受容体やイ オンチャネルなどの膜タンパク質も分解されな い. ${ }^{11,12)}$ 細胞シートにはフィブロネクチンなどの細 胞接着分子が保持されているため, 他の細胞や組織 に重層することが可能である，現在では，角膜，歯 周組織, 食道や心筋など様々な組織の再生や臨床に 応用されている. ${ }^{13,14)}$

筆者らはこの技術を用いて, ヒト肝細胞株 HepG2 にウシ血管内皮細胞シートを重層した肝・内皮重層 化培養系を作製した。 HepG2 はヒト肝細胞の特徵 を保持した細胞株として広く用いられているが，初 代培養肝細胞に比べて, 肝特異的因子であるアルブ

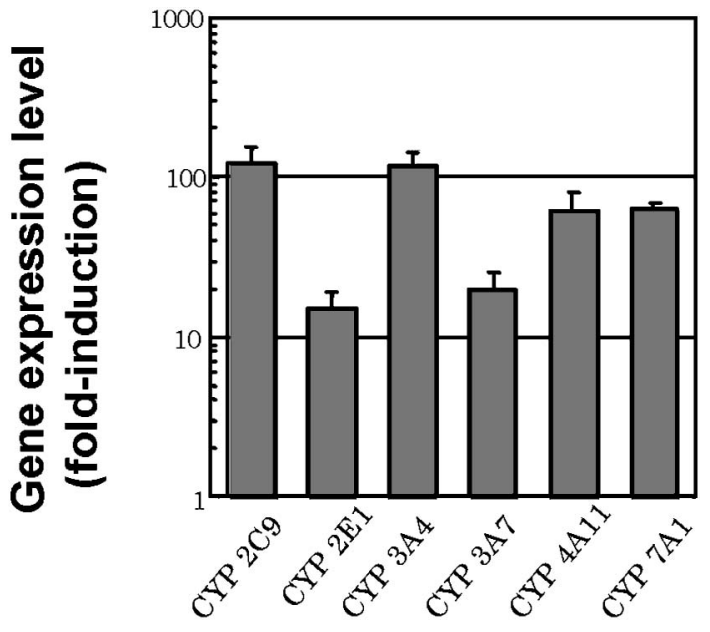

Fig. 3. Comparison of Expression Levels of the Cytochrome P450 Genes between Monolayer Culture and Layered Coculture at 21 Days after Overlaying a Bovine Pulmonary Artery Endothelial Cell (BPAEC) Sheet onto Hepatic HepG2 Cells

ミンや薬物代謝関連遺伝子の発現が極めて低い。ま た，ヒト初代培養肝細胞は入手が困難であり，肝機 能が数日で著しく低下するという欠点がある. 一方 で，われわれが構築した HepG2 を用いた肝・内皮 重層化培養系ではアルブミンなどの血清タンパク質 や薬物代謝関連遺伝子の発現が大きく上昇してい た. ${ }^{15-17)}$

われわれはこの実験系を薬物代謝試験に応用する ことを考え，さらに詳細に薬物代謝酵素遺伝子の発 現を調べた。 その結果, 薬物代謝の第一相反応にお いて中心的役割を担うシトクロム P450（CYP） は 様々なアイソザイムにおいて, HepG2 単独培養に 比べ 10 倍以上の発現上昇がみられた（Fig. 3)。中 でも CYP4A11 遺伝子はヒト肝組織と同程度の発現 を示した. ${ }^{18)}$ また，この重層化共培養系では CYP 誘導剂であるフェノバルビタールによって CYP2C9 やCYP3A4 遺伝子の発現誘導が初代培養肝細胞を 用いた解析と同程度のレベルでみられた。さらに,

CYP3A4 については薬物濃度依存的な酵素活性上

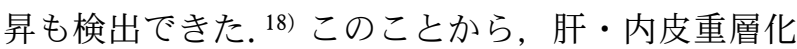
培養により肝細胞の機能が活性化され, 薬物代謝酵 素の誘導が検出されたと考えられた。

この重層化共培養系におけるアルブミンや CYP 遺伝子の発現変化は比較的緩やかで, 重層後 10 日 過ぎから上昇をはじめ, 20 日後にピークに達し た. ${ }^{15,17)}$ 重層化共培養の断面図を共焦点レーザー顕 
微鏡により観察すると，細胞層は重層後に徐々に厚 みを増し，重層 20 日後には 2.4 倍，核の厚みは 1.6 倍に肥厚し立方状の形態となっていった，肝細胞の 形態と機能には相関があることが知られている．肝 細胞と ECM との接着面積が小さく, 肝細胞が立体 的な形態をとるときほどアルブミン分泌能が高まる ということが知られている. ${ }^{19,20)}$ このことから，内 皮細胞の重層化による ECM 構築の違いが，肝細胞 の形態を変化させ肝特異的な機能が活性化されたと 予想される。 さらに ECM のジオメトリーだけでな $<, \mathrm{ECM}$ 成分も肝細胞の機能に大きく影響を与え ていることがわかっている。そこでわれわれは, 肝・内皮重層化共培養における ECM と細胞接着関 連遺伝子の発現変化を，これらの 84 種類の遺伝子 について PCR Array を用いて検討した。 その結果, HepG2 単独培養と比較して, 30 種類以上の遺伝子 の発現が変化していることがわかつた. ${ }^{21)}$ 例えば, ECM に結合する細胞表面受容体の 1 つであるヒト 型インテグリン $\alpha 4$ 遺伝子の発現は, 重層化培養に おいて重層 20 日後にピークを示し, 6.8 倍上昇し ていた（Fig. 4).HepG2 表面のインテグリンを介 した細胞内情報伝達の変化が, HepG2 の活性化に 影響を与えた可能性がある。 また，プロテオグリカ ンの 1 つであるウシ型デコリン遺伝子の発現は, 重 層後 15 日後にピークを示し，5倍上昇していた (Fig. 4)。デコリンはコラーゲンなどの ECM タン パク質や増殖因子と結合することによって, 細胞内 に伝達されるシグナルを調節している。このような $\mathrm{ECM}$ の変化による細胞内シグナル伝達経路の活性 化が，肝細胞の機能を高める一因になっていると考 えている.
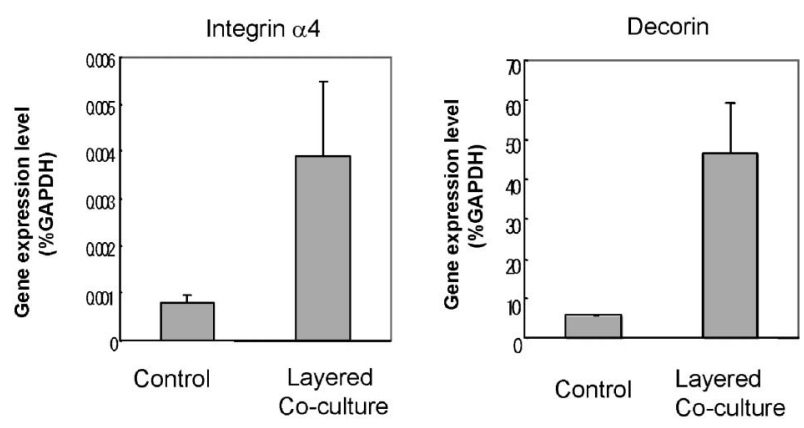

Fig. 4. Comparison of Human Integrin $\alpha 4$ and Decorin Gene Expression Levels between Layered Co-culture Cells and Monolayer Cultured HepG2 Cells (control) at 14 Days after Overlaying BPAEC Sheet onto HepG2 Cells
以上のように, 肝・内皮重層化培養における肝細 胞の活性化には ECM のジオメトリーが重要である ことが予想された。また，重層化によって発現の変 化がみられた ECM の構成成分や細胞接着因子は非 常に多いという事実から，この培養系における肝細 胞の特異的な機能の発現に, ECM を構成する成分 が複雑に影響していると予想される。今後はより詳 細な検討を行い，ECM 成分を人工的に制御するこ とで，細胞機能を活性化できるようになればよいと 考えている.

\section{3. 細胞毒性を感知するセンサ細胞}

細胞は外的刺激や環境の変化に応じて遺伝子の発 現を変化することにより恒常性を維持している。こ の応答は非常に高感度かつ迅速な応答なので，この 応答を可視化できれば細胞を毒性などのセンサとし て利用することができる (センサ細胞)。22-27)一方 で，マイクロ流路は物質や細胞の分離や微量計測に 利用されている，マイクロ流路内では表面張力が優 位に働くために，乱流が起こり難く，一定の流速が あれば層流を作ることが可能である.われわれはこ の点に注目し，センサ細胞とマイクロ流路を用い て，ハイスループットな薬物毒性評価システムの構 築を試みた。

センサ細胞は Fig. 5 に示すように作成した。細 胞毒性に応答する遺伝子のプロモーターの下流にホ タルのルシフェラーゼやクラゲの蛍光タンパク質で ある GFP を接続し，ヒトを始めとする動物細胞に 組み込んだ。このセンサ細胞は細胞毒性に応答し, 発光や蛍光で可視化することができる．センサ細胞

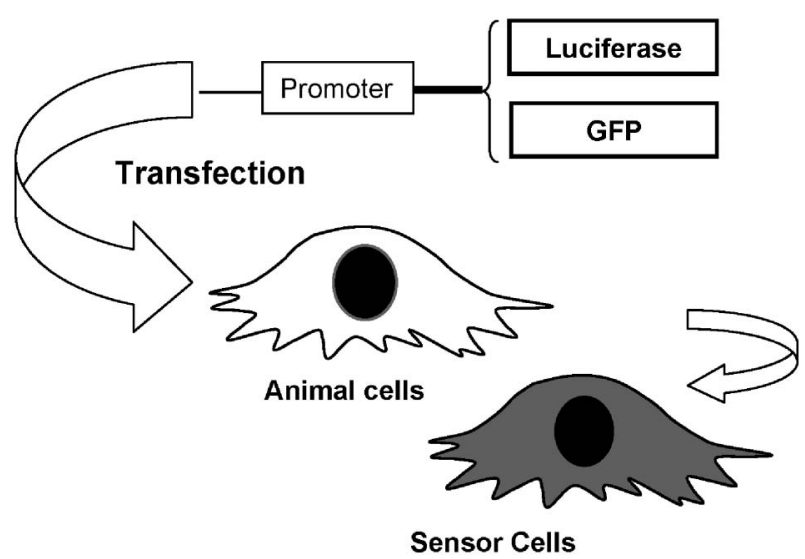

Fig. 5. Construction of Sensor Cells

Sensor cells were constructed by transfected gene which contained promoter and reporter genes such as luciferase or GFP to animal cells. 
を作成するために，われわれはまず，熱ショックタ ンパク質 70B' (HSP70B') のプロモーターに注目 した。HSP70B’は温度刺激だけでなく，重金属な どの細胞内タンパク質の変性などに対して広くか つ，高感度に応答することが知られている。 そこ で，われわれは HSP70B' のプロモーターの下流に ルシフェラーゼを接続したプラスミドを HepG2 細 胞に導入して塩化カドミウムに対する応答を調べ た。その結果，既存のATP 放出を指標とした細胞 毒性の測定方法より，5倍近く検出限界が低いこと が明らかになった（Fig. 6). ${ }^{22)}$ 次に，HSP70B’の

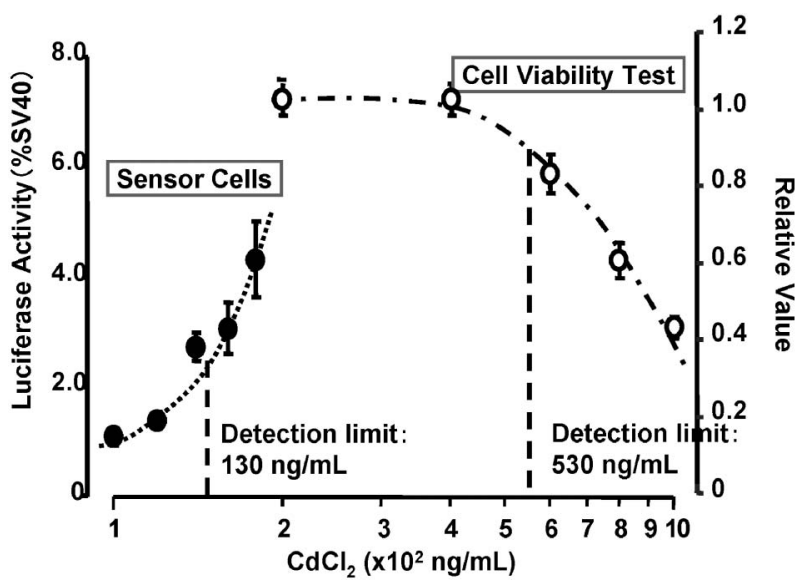

Fig. 6. Standard Curve for $\mathrm{CdCl}_{2}$ Using Sensor Cells and Cell Viability Test

Detection limit for cadmium chloride with sensor cells was $130 \mathrm{ng} / \mathrm{ml}$. On the other hand, detection limit using cell vialbility test was $530 \mathrm{ng} / \mathrm{ml}$. These results indicated that the sensor cells have significant advantages for the detection of cytotoxicity in sensitivity, when compared to the cell viability test.
プロモーターの下流に GFP を挿入したプラスミド を作成した。このプラスミドを NIH3T3 細胞に導 入し，薬剂耐性を指標に選択し細胞株を得た。この 細胞株は塩化力ドミウムに対し，容量依存的に蛍光 強度が増加した．2-6 $\mu \mathrm{g} / \mathrm{ml}$ のレンジで検出可能だ つた. 次に，センサ細胞株の塩化カドミウム添加後 の蛍光強度の時間変化について検討した。その結 果，蛍光強度は 12 時間をピークに増加し，12 時間 後から低下した。細胞死の判定には 24 時間必要な ので，センサ細胞を用いた毒性評価方法は短時間に 判定できるという利点がある。 以上の結果から，作 成したセンサ細胞株は定量的に細胞毒性を検出でき ると考えられた．われわれはDNA に作用する細胞 毒性を感知するセンサ細胞も BTG2 という遺伝子 のプロモーターを用いて作製に成功している. ${ }^{27)}$

トップダウンによるナノ・マイクロ加工技術はナ ノテクノロジーの発展に伴い，バイオ利用が可能に なってきている。このナノ・マイクロ加工技術を用 いて細胞毒性検出用のマイクロ流路を作成した。こ の流路にセンサ細胞株を培養し, 細胞毒性を検出す るハイスループットなナノバイオデバイスの開発を 行つた. マイクロ流路内では表面張力が優位に働く ために，一定の流速があれば層流を作ることができ る.われわれは 3 つの入路があり，1 つの出口を持 つマイクロ流路内にセンサ細胞を培養した。 その上 に濃度の異なる塩化カドミウムの層流を作成し，塩 化力ドミウムの細胞毒性の検出を行つた（Fig. 7).

$9 \mu \mathrm{g} / \mathrm{ml}$ （図上）では強い蛍光を示し， $4 \mu \mathrm{g} / \mathrm{ml}$ (中

Fluorescent (relative value)

$9 \mu \mathrm{g} / \mathrm{mL}$

$4 \mu \mathrm{g} / \mathrm{mL}$
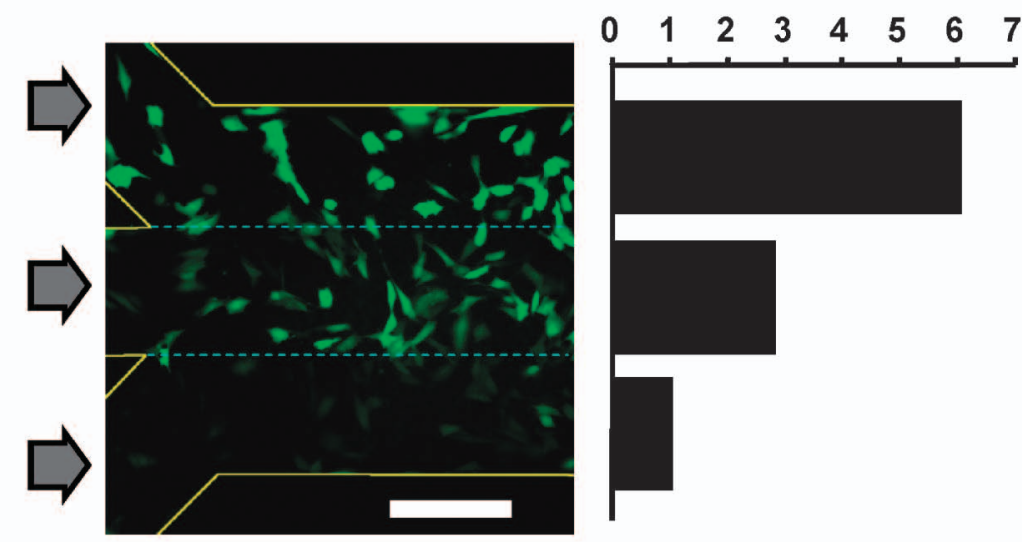

bar $=200 \mu \mathrm{m}$

Fig. 7. Cytotoxic Response of the Sensor Cell Line in the 3-inlet Microfluidic Channels Fluorescence in the sensor cells increased in a $\mathrm{CdCl}_{2}$ dose-dependent manner in the microfluidic channels. 
央）では弱い蛍光を示した。このように，細胞毒性 を検出できるハイスループットなナノバイオデバイ スの開発に成功した. ${ }^{26)}$ さらに，われわれは自動的 に段階的な希釈を行えるマイクロ流路を作製した。 そこに，センサ細胞を培養し，塩化カドミウムの細 胞毒性を測定した。その結果，塩化カドミウムの濃

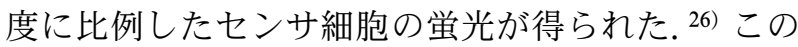
測定系は非常に少ないサンプル量で測定が可能であ り，流路を増やすことにより，同一条件下で多検体 の測定が可能になる。いわゆる，ハイスループット 分析が可能である。.また，センサ細胞の種類を増や すことにより，細胞毒性の原因も簡単にわかるよう になるであろう。すなわち，DNA に対する毒性に 応答するセンサ細胞（BTG2 を用いたセンサ細胞） と HSP70B’を用いたセンサ細胞を用いれば，タン パク質の変性に伴う毒性なのか，DNA に対する毒 性なのかも判別が可能になる。この測定系は医薬品 の毒性スクリーニングに利用できると考えている.

\section{4. おわりに}

以上のように，われわれはナノ・バイオテクノロ ジーを用いて肝・内皮重層化培養とセンサ細胞を用 いたハイスループットな細胞毒性の評価系を開発し た。肝・内皮重層化培養では, HepG2 というがん 細胞株を用いても十分薬物代謝試験を行えることを 示すことができた。 また，センサ細胞を用いた細胞 毒性の検出は高感度で，多検体同時測定が可能な方 法である. 今後はこれらの培養系を動物実験や従来 の細胞実験にとって代わって，創薬支援技術として 用いられるようにさらに改良を加えていきたいと考 えている.

謝辞本研究は東京女子医科大学岡野光夫, 大 和雅之, 小林純, 系賀各先生方との共同研究で遂行 されました。また，多くのご助言を頂いた明治薬科 大学の本島清人先生に感謝いたします.

\section{REFERENCES}

1) Baranczewski P., Stanczak A., Sundberg K., Svensson R., Wallin A., Jansson J., Garberg P., Postlind H., Pharmacol. Rep., 58, 453472 (2006).

2) Raucy J. L., Drug Metab. Dispos., 31, 533539 (2003).
3) LeCluyse E. L., Eur. J. Pharm. Sci., 13, 343368 (2001).

4) Worboys P. D., Carlile D. J., Xenobiotica, 31, 539-556 (2001)

5) Jigorel E., Le Vee M., Boursier-Neyret C., Bertrand M., Fardel O., Drug Metab. Dispos., 33, 1418-1422 (2005).

6) Payen L., Courtois A., Campion J. P., Guillouzo A., Fardel O., Biochem. Pharmacol., 60, 1967-1975 (2000).

7) Payen L., Sparfel L., Courtois A., Vernhet L., Guillouzo A., Fardel O., Cell Biol. Toxicol., 18, 221-233 (2002).

8) Binda D., Lasserre-Bigot D., Bonet A., Thomassin M., Come M. P., Guinchard C., Bars R., Jacqueson A., Richert L., Toxicol. in Vitro, 17, 59-67 (2003).

9) Rodriguez-Antona C., Donato M. T., Boobis A., Edwards R. J., Watts P. S., Castell J. V., Gomez-Lechon M. J., Xenobiotica, 32, 505520 (2002).

10) Wilkening S., Stahl F., Bader A., Drug Metab. Dispos., 31, 1035-1042 (2003).

11) Okano T., Yamada N., Sakai H., Sakurai Y., J. Biomed. Mater. Res., 27, 1243-1251 (1993).

12) Okano T., Yamada N., Sakai H., Sakurai Y., Biomaterials, 16, 297-230 (1995).

13) Nishida K., Yamato M., Hayashida Y., Watanabe K., Yamamoto K., Adachi E., Nagai S., Kikuchi A., Maeda N., Watanabe H., Okano T., Tano Y., N. Engl. J. Med., 351, 1187-1196 (2004).

14) Shimizu T., Yamato M., Isoi Y., Akutsu T., Setomaru T., Abe K., Kikuchi A., Umezu M., Okano T., Circ. Res., 90, e40-e48 (2002).

15) Kurosawa Y., Taniguchi A., Okano T., Tissue Eng., 11, 1650-1657 (2005).

16) Takayama G., Taniguchi A., Okano T., Tissue Eng., 13, 159-166 (2007).

17) Ohno M., Motojima K., Okano T., Taniguchi A., Tissue Eng., 14, 1861-1869 (2008)

18) Ohno M., Motojima K., Okano T., Taniguchi A., Biol. Pharm. Bull., 32, 813-817 (2009) .

19) Wang N., Butler J., Ingber D., Science, 260, 1124-1127 (1993).

20) Mooney D., Langer R., Ingber D., J. Cell Sci., 108, 2311-2320 (1995).

21) Ohno M., Motojima, K., Okano T., 
Taniguchi, A., J. Biochem., 145, 591-597 (2009)

22) Wada K-I., Taniguchi A., Xu L., Okano T., Biotechnol. Bioeng., 92, 410-415 (2005).

23) Okuda-Shimazaki J., Wada K-I., Taniguchi A., Open Biotechnol. J., 1, 31-33 (2007).

24) Wada K-I., Taniguchi A., Okano T., Biotechnol. Bioeng., 97, 871-876 (2007) .
25) Wada K-I., Okuda-Shimazaki J., Taniguchi A., Open Biotechnol. J., 1, 21-25 (2007) .

26) Wada K-I., Taniguchi A., Kobayashi J., Yamato M., Okano T., Biotechnol. Bioeng., 99, 1513-1517 (2008).

27) Wada K-I., Hamaguchi Y., Furukawa K., Taniguchi A., Biotechnol. Bioeng., 102, 14601465 (2009). 